\title{
Short term effects of air pollution on mortality in the city of Lyon, France, 1985-90
}

\author{
D Zmirou, T Barumandzadeh, F Balducci, P Ritter, G Laham, J-P Ghilardi
}

\begin{abstract}
Objective - The short term association between daily mortality and ambient air pollution in the city of Lyon, France (population, 410 000) between 1985 and 1990 was assessed using time series analysis.

Design - This study followed the standardised design and statistical analysis (Poisson regression) that characterise the APHEA project.

Methods - Four categories of cause of death were studied: total (minus external causes), respiratory, cardiovascular, and digestive causes (as a control condition). Results - No association was found with any cause of death for nitrogen dioxide $\left(\mathrm{NO}_{2}\right)$ and ozone $\left(\mathrm{O}_{3}\right)$, nor, for any pollutant, for digestive conditions. Sulphur dioxide $\left(\mathrm{SO}_{2}\right)$ and, to a much lesser degree, suspended particles $\left(\mathbf{P M}_{13}\right)$, were significantly related to mortality from respiratory and cardiovascular conditions. The relative risk (RR) of respiratory deaths associated with a $50 \mu \mathrm{g} / \mathrm{m}^{3}$ increment of mean daily $\mathrm{SO}_{2}$ over the whole period was $1.22(95 \%$ CI $1.05,1.40)$; the RR for cardiovascular deaths was $1.54(1 \cdot 22,1 \cdot 96)$. The corresponding $R R$ for $\mathbf{P M}_{13}$ were 1.04 $(1.00,1.09)$ for respiratory mortality and $1.04(0.99,1 \cdot 10)$ for cardiovascular deaths. Conclusions - The effects of particulates were slightly increased during the cold season. When particulates concentrations were greater than $60 \mu \mathrm{g} / \mathrm{m}^{3}$, the joint $\mathrm{SO}_{2}$ effect was increased, suggesting some interaction between the two pollution indicators. These results agree with other studies showing an association between particulate pollution and daily mortality; however, they also suggest the noxious effect of $\mathrm{SO}_{2}$.
\end{abstract}

( $($ Epidemiol Comm Health 1996;50(Suppl 1):S30-S35)

Joseph Fourier,

Joseph Fourier,

G Zmirou

F Balducci

Labsad, UFR de

Mathématiques et

Sciences Humaines,

Université Pierre

Mendès-France,

Grenoble

Grenoble

G Laham

Hygiene Laboratory, Lyon, France

$P$ Ritter

J-P Ghilardi

Correspondence to:

Dr D Zmirou, Department

de Santé Publique, Domaine

de la Merci, 38706 La

Tronche Cedex, France. these findings and because the air pollution make up may be different in European countries, it was decided to launch a European collaborative study on air pollution and mortality and morbidity using time series data the APHEA project (Air Pollution and Health; a European Approach). ${ }^{15}$

In this context, the city of Lyon, France, presented interesting features for such a study. It is the third largest town in the country (410 000 inhabitants) after Paris and Marseille, and its air pollution monitoring network has been working for a long time, showing that air pollution is still rather high compared with other French cities. The annual mean concentrations for sulphur dioxide $\left(\mathrm{SO}_{2}\right)$ and nitrogen dioxide $\left(\mathrm{NO}_{2}\right)$ in 1990 were $48 \mu \mathrm{g} / \mathrm{m}^{3}$ and $70 \mu \mathrm{g} / \mathrm{m}^{3}$ in Lyon, compared with $27 \mu \mathrm{g} / \mathrm{m}^{3}$ and $53 \mu \mathrm{g} / \mathrm{m}^{3}$ as averages of all urban networks in France. The $\mathrm{SO}_{2}$ annual average concentrations are much higher (double) than in Paris and Marseille, due to the proximity of an important chemical industry site in the south of the city, while the values for $\mathrm{NO}_{2}$ and particulates are similar between the three cities. ${ }^{16-17}$ These average concentrations are also relatively high compared with the other western European cities involved in the APHEA project. ${ }^{15}$ Using data collected in Lyon in 1974-76, a preceding paper had shown that daily mortality from respiratory conditions was significantly associated with $\mathrm{SO}_{2}$, with a lag running up to 10 days, but not with suspended particulates, measured as black smoke. ${ }^{18}$ Results of the recent short term mortality studies are, however, most consistent for particulates and specifically those indexed as inhalable particles $\left(\mathrm{PM}_{10}\right)$ or fine particles $\left.\left(\mathrm{PM}_{2 \cdot 5}\right)\right)^{126-11}$ Traditional industrial sources of $\mathrm{SO}_{2}$ emissions have been efficiently controlled in France, as in most western European countries. By substituting other sources of energy for heavy fuels or coal and by building high stacks with filters, ambient $\mathrm{SO}_{2}$ concentrations have been dramatically reduced over the past three decades. Particles and $\mathrm{NO}_{2}$ have not shown such a positive evolution, due to the growing contribution of automobile emissions. ${ }^{1719}$ The physico-chemical nature of particulates has also changed over time, since their main sources have switched from industrial processes to transport emissions and, to a lesser degree, to urban heating. Therefore, the associations observed in 1974-76 may not hold true 10 to 15 years later.

\section{Methods}

The study period was $1985-90$ inclusive. Air polution data were provided by the Laboratory of Hygiene, Lyon, which manages the met- 
Table 1 Air pollution and meteorology characteristics in Lyon, 1985-90

\begin{tabular}{|c|c|c|c|c|c|}
\hline \multirow[t]{2}{*}{ Meteorology/pollutant } & \multicolumn{5}{|l|}{ Period } \\
\hline & Winter & Summer & Spring & Autumn & Whole period \\
\hline \multicolumn{6}{|l|}{ Temperature $\left({ }^{\circ} \mathrm{C}\right)$} \\
\hline Mean & $3 \cdot 32$ & $10 \cdot 86$ & $20 \cdot 06$ & $12 \cdot 35$ & $11 \cdot 69$ \\
\hline Minimum & -13.86 & 0.05 & $9 \cdot 89$ & -2.98 & $-13 \cdot 86$ \\
\hline Maximum & $16 \cdot 76$ & $21 \cdot 26$ & $28 \cdot 81$ & $24 \cdot 14$ & $28 \cdot 81$ \\
\hline \multicolumn{6}{|l|}{ Humidity } \\
\hline Mean & $83 \cdot 23$ & $72 \cdot 23$ & $66 \cdot 34$ & $78 \cdot 15$ & $74 \cdot 89$ \\
\hline Minimum & $54 \cdot 25$ & $39 \cdot 25$ & 38.63 & $44 \cdot 50$ & $38 \cdot 63$ \\
\hline Maximum & $100 \cdot 00$ & $97 \cdot 38$ & $95 \cdot 88$ & $100 \cdot 00$ & $100 \cdot 00$ \\
\hline \multicolumn{6}{|l|}{$\mathrm{SO}_{2}$ mean* } \\
\hline Mean & $76 \cdot 76$ & $42 \cdot 22$ & $26 \cdot 39$ & $42 \cdot 10$ & $46 \cdot 76$ \\
\hline Minimum & $12 \cdot 93$ & 6.77 & $2 \cdot 16$ & $3 \cdot 37$ & $2 \cdot 16$ \\
\hline Maximum & 314.57 & 157.96 & $86 \cdot 65$ & 149.99 & $314 \cdot 57$ \\
\hline \multicolumn{6}{|l|}{$\mathrm{SO}_{2}$ maximum } \\
\hline Mean & $148 \cdot 33$ & $93 \cdot 83$ & $61 \cdot 22$ & $98 \cdot 50$ & $100 \cdot 22$ \\
\hline Minimum & $29 \cdot 75$ & $15 \cdot 31$ & $4 \cdot 71$ & $7 \cdot 61$ & $4 \cdot 71$ \\
\hline Maximum & $635 \cdot 69$ & $509 \cdot 50$ & $436 \cdot 68$ & $504 \cdot 38$ & $635 \cdot 69$ \\
\hline \multicolumn{6}{|l|}{$P M_{13}$ mean $\dagger$} \\
\hline Mean & $51 \cdot 00$ & $35 \cdot 79$ & $27 \cdot 91$ & $37 \cdot 59$ & 38.05 \\
\hline Minimum & $6 \cdot 48$ & $3 \cdot 82$ & $4 \cdot 81$ & $2 \cdot 67$ & $2 \cdot 67$ \\
\hline Maximum & $179 \cdot 81$ & $124 \cdot 51$ & $97 \cdot 54$ & $132 \cdot 17$ & $179 \cdot 81$ \\
\hline \multicolumn{6}{|l|}{$\mathrm{NO}_{2}$ mean $\ddagger$} \\
\hline Mean & $67 \cdot 08$ & $71 \cdot 70$ & $67 \cdot 46$ & $75 \cdot 60$ & $70 \cdot 17$ \\
\hline Minimum & 3.50 & $8 \cdot 52$ & $4 \cdot 62$ & $11 \cdot 78$ & $3 \cdot 50$ \\
\hline Maximum & 323.75 & $226 \cdot 40$ & $194 \cdot 74$ & 193.86 & 323.75 \\
\hline \multicolumn{6}{|l|}{$\mathrm{NO}_{2}$ maximum } \\
\hline Mean & $117 \cdot 72$ & $147 \cdot 18$ & $133 \cdot 48$ & $132 \cdot 83$ & $132 \cdot 73$ \\
\hline Minimum & $9 \cdot 55$ & $17 \cdot 19$ & $11 \cdot 46$ & $19 \cdot 57$ & $9 \cdot 55$ \\
\hline Maximum & $716 \cdot 25$ & $737 \cdot 26$ & $485 \cdot 14$ & $428 \cdot 28$ & $737 \cdot 26$ \\
\hline \multicolumn{6}{|l|}{$\mathrm{O}_{3}$ mean $\S$} \\
\hline Mean & $8 \cdot 45$ & $13 \cdot 21$ & $12 \cdot 13$ & $5 \cdot 57$ & $9 \cdot 94$ \\
\hline Minimum & 0.0 & 0.0 & 0.0 & $0 \cdot 0$ & 0.0 \\
\hline Maximum & $35 \cdot 75$ & $71 \cdot 23$ & $78 \cdot 92$ & 22.92 & 78.92 \\
\hline \multicolumn{6}{|l|}{$\mathrm{O}_{3}$ maximum } \\
\hline Mean & $11 \cdot 85$ & $19 \cdot 55$ & $20 \cdot 10$ & $9 \cdot 29$ & $15 \cdot 23$ \\
\hline Minimum & 0.0 & 0.0 & 0.0 & 0.0 & 0.0 \\
\hline Maximum & $44 \cdot 0$ & $98 \cdot 0$ & $152 \cdot 0$ & $52 \cdot 0$ & $152 \cdot 0$ \\
\hline
\end{tabular}

* $5 \cdot 1 \%$ missing data; $\nmid 10.0 \%$ missing data; $¥ 22.5 \%$ missing data; $₫ 12.6 \%$ missing data.

ropolitan air quality monitoring network (COPARLY). In order to facilitate comparisons between results of APHEA cities, strict rules were set for the assessment of population exposure. ${ }^{20}$ Daily mean or hourly maximum values for $\mathrm{SO}_{2}$ (whole day), $\mathrm{NO}_{2}$ (whole day) and ozone $\left(\mathrm{O}_{3}\right)$ ( 9 am to $5 \mathrm{pm}$ for the mean and 6 am to $7 \mathrm{pm}$ for the maximum) were used, along with daily means for particle concentrations. The measurement methods used by the Lyon monitoring network are ultraviolet fluorescence for $\mathrm{SO}_{2}$, chemiluminescence for $\mathrm{NO}_{2}$, ultraviolet absorption for $\mathrm{O}_{3}$, and $\beta$-ray atomic absorption for particulates (with a cut off point about $13 \mu \mathrm{m}$, which gives results essentially identical to the more classical $\mathbf{P M}_{10}$ techniques). Means were calculated over all the relevant monitoring stations available within the limits of the city of Lyon (five sites for $\mathrm{SO}_{2}$, three sites for $\mathrm{PM}$, one for $\mathrm{NO}_{2}$, and one for $\mathrm{O}_{3}$ ). Maximums were taken as the averages of the higher one hour values over all the relevant monitoring stations. These stations were chosen in order to represent the background air quality levels. For this reason, one monitor was excluded. It was positioned in a place with a very high traffic density; its mean and maximum values for $\mathrm{PM}, \mathrm{NO}_{2}$, and even $\mathrm{SO}_{2}$ (also associated with diesel sulphur emissions) were clearly outliers compared with the other sites (1985-89 average of daily means: $86 \mu \mathrm{g} /$ $\mathrm{m}^{3}$ for $\mathrm{SO}_{2}, 74 \mu \mathrm{g} / \mathrm{m}^{3}$ for PM and $92 \mu \mathrm{g} / \mathrm{m}^{3}$ for $\mathrm{NO}_{2}$ in the central site).

In case one monitoring station had, for technical reasons, a missing value for one pollutant on a given day, this value was estimated using the average of the measurements of the other available stations. The ratio between the mean values of this station and the mean values of the other stations, for the same year and season, was used to correct for this substitution. When all stations had missing values, no substitution could be made. In the case of $\mathrm{NO}_{2}$ (for which there was only one remaining station), the missing values were completed by using the measurements of the central station that had been discarded when available. For this substitution, the $\mathrm{NO}_{2}$ values were also corrected using the ratio of the mean daily concentration of both sites, for the same year and season. With $\mathrm{O}_{3}$, for which only one station was available, no substitution could be made for missing values. The location of this $\mathrm{O}_{3}$ monitor, within the urban centre of Lyon, raises the question of its relevance to $\mathrm{O}_{3}$ population exposure (due to scavenging by NO).

Table 1 provides descriptive daily data on air pollution and meteorology in Lyon over the period 1985-90 in relation to season.

Mortality data were also provided by the Laboratory of Hygiene, Lyon. Daily counts of total deaths minus deaths external causes (ICD-9 codes <800), total deaths from respiratory diseases (ICD-9 codes 460-519), total deaths from cardiovascular diseases (ICD-9 codes 390-429), and total deaths from digestive diseases (ICD-9 codes 520-579) were chosen for this analysis, based on the published reports. The latter was used as a control condition, for which no association with air pollution was expected. Table 2 gives descriptive daily data for these mortality categories during the study period. Only deaths occurring in Lyon to residents of the city were considered, excluding those registered in other cities of the country or the Lyon metropolitan area. The reason 
Table 2 Mortality in Lyon in relation to cause and season 1985-90 (number of daily events)*

\begin{tabular}{|c|c|c|c|c|c|}
\hline \multirow[t]{2}{*}{ Deaths } & \multicolumn{5}{|l|}{ Period } \\
\hline & Winter & Spring & Summer & Autumn & Whole period \\
\hline \multicolumn{6}{|c|}{ Total deaths minus external causes } \\
\hline Mean & $7 \cdot 63$ & $6 \cdot 69$ & $5 \cdot 97$ & $6 \cdot 20$ & $6 \cdot 43$ \\
\hline Minimum & 0 & 0 & 1 & 0 & \\
\hline Maximum & 18 & 15 & 15 & 15 & 18 \\
\hline \multicolumn{6}{|c|}{ Respiratory causes } \\
\hline Mean & $0 \cdot 63$ & $0 \cdot 47$ & $0 \cdot 34$ & $0 \cdot 34$ & $0 \cdot 40$ \\
\hline Minimum & 0 & 0 & 0 & 0 & 0 \\
\hline Maximum & 5 & 5 & 3 & 3 & 3 \\
\hline \multicolumn{6}{|c|}{ Cardiovascular causes } \\
\hline Mean & $2 \cdot 45$ & $2 \cdot 09$ & 1.68 & 1.93 & $2 \cdot 04$ \\
\hline Minimum & 0 & 0 & 0 & 0 & 0 \\
\hline Maximum & 8 & 9 & 6 & 8 & 9 \\
\hline \multicolumn{6}{|c|}{ Digestive causes } \\
\hline Mean & $0 \cdot 41$ & $0 \cdot 39$ & $0 \cdot 34$ & $0 \cdot 36$ & $0 \cdot 38$ \\
\hline Minimum & 0 & 0 & 0 & 0 & 0 \\
\hline Maximum & 3 & 3 & 4 & 3 & 4 \\
\hline
\end{tabular}

$*_{1} \cdot 1 \%$ missing data $(0 \%-2 \cdot 7 \%$ according to season)

Table 3 Descriptive and confounding variables included in the final models

\begin{tabular}{|c|c|c|c|}
\hline Total external causes & Respiratory deaths & Cardiovascular deaths & Digestive deaths \\
\hline Trend (linear + quadratic) & Trend (linear) & Trend (linear + quadratic) & Trend (linear) \\
\hline 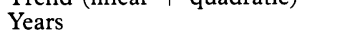 & Years & Years & Years \\
\hline Sin 1 & Sin 2 & Sin 1 & Sin 1 \\
\hline $\operatorname{Cos} 1$ & $\operatorname{Cos} 2$ & $\operatorname{Cos} 1$ & $\operatorname{Cos} 1$ \\
\hline $\operatorname{Sin} 2$ & $\operatorname{Sin} 3$ & $\operatorname{Sin} 5$ & $\operatorname{Sin} 2$ \\
\hline $\operatorname{Cos} 2$ & $\operatorname{Cos} 3$ & $\operatorname{Cos} 5$ & $\operatorname{Cos} 2$ \\
\hline $\sin 3$ & Days of week & $\operatorname{Sin} 6$ & Days of week \\
\hline Cos 3 & Hot season & $\operatorname{Cos} 6$ & Hot season \\
\hline Days of week & Temperature & Days of week & $\begin{array}{l}\text { Temperature (linear }+ \\
\text { quadratic) }\end{array}$ \\
\hline Holidays & Humidity (lag 0-2) & Hot season & Humidity \\
\hline Temperature (linear + quadric) & (linear + quadratic) & Temperature & Influenza epidemic \\
\hline Humidity & Influenza epidemic & Humidity (lag 1) & \\
\hline Autocorrelation & & (linear + quadratic) & \\
\hline
\end{tabular}

for this selection was to provide a reasonable estimation of the true ambient air exposure of the population at risk.

The statistical analysis followed the time series protocol established by all the APHEA participants. ${ }^{2021} \mathrm{~A}$ Poisson time series regression was chosen because it yields directly relative risks which are easily comparable across the different APHEA cities, whose sizes vary a lot. The relation between air pollution and mortality was assessed after controlling for the best fit time patterns and weather factors. The descriptive and confounding variables that were used in the models are presented, for each pollutant, in table 3 , including, when relevant, autocorrelation terms. Forward inclusion of descriptive and confounding variables was first

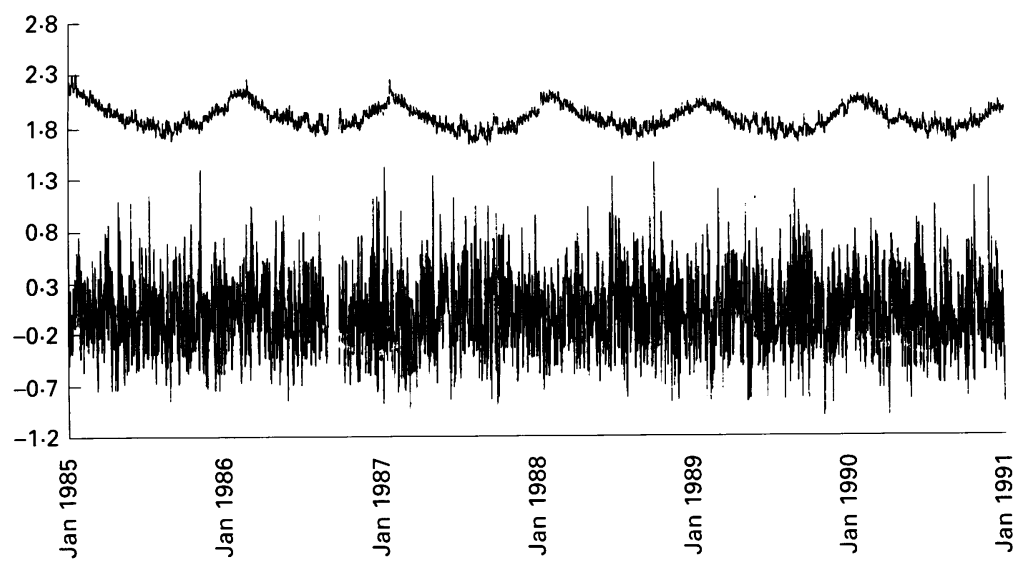

Figure 1 Predicted $(\log X+1)$ counts and residuals of the descriptive model for total mortality (minus external causes), including temporal and meteorological variables (variables in table 3). done through linear regression modelling where the Wald statistic was the criteria for variable selection (the decision limit of the $\mathrm{p}$ value was set at $0 \cdot 10$, not to overlook some residual confounding). Some core variables (sinusoidal terms for long wave seasonality, week patterns, temperature, and relative humidity) were forced into the model in all cities irrespective of their statistical significance. Other variables could be included by each APHEA participant to fit local patterns of the data (year variables, holidays, influenza epidemics etc). Figure 1 shows the residuals of the final descriptive model for total mortality minus external causes in Lyon, before the inclusion of air pollution variables.

Three models were tested for each pollutant: the crude concentrations and log or square transformations. The improvement in adjusted $\mathrm{R}^{2}$ in the linear regression was used to choose the best transform. Also, for each exposure variable (daily mean or maximum hourly values), two types of lags were used: the best fitted one day lag (up to three days for $\mathrm{SO}_{2}$, $\mathrm{PM}_{10}$, or $\mathrm{NO}_{2}$, up to four days for $\mathrm{O}_{3}$ ) and the average of daily concentrations over several days (up to three to four days), representing some index of cumulative exposure. Furthermore, seasonal variations in the effect of the pollutants were assessed, introducing an interaction term for hot/cold season (for Lyon, "hot season" was defined as days between 1 March and 31 October). The interaction between pollutants that was the most interesting $\left(\mathrm{SO}_{2}\right.$ and $\left.\mathrm{PM}_{13}\right)$ was studied by dividing the data set according to $\mathrm{PM}_{13}$ concentrations ("high", defined as values above $60 \mu \mathrm{g} / \mathrm{m}^{3}$, and 
Table 4 Relative risks of mortality in relation to cause (and $95 \%$ confidence interval) associated with a $50 \mu \mathrm{g} / \mathrm{m}^{3}$ increase in the level of pollutants over the whole $1985-90$ period, in Lyon, France

\begin{tabular}{|c|c|c|c|c|c|c|c|}
\hline \multirow[t]{2}{*}{ Concentrations } & \multicolumn{2}{|l|}{$\mathrm{SO}_{2}$} & \multirow{2}{*}{$\frac{P M_{13}}{\text { Mean }}$} & \multicolumn{2}{|l|}{$\mathrm{NO}_{2}$} & \multicolumn{2}{|l|}{$\mathrm{O}_{3}$} \\
\hline & Mean & Maximum & & Mean & Maximum & Mean & Maximum \\
\hline Total minus external causes & $\begin{array}{c}1.06(\mathrm{t}-0)^{*} \\
(1.09,1.02)\end{array}$ & $\begin{array}{c}1.29(\mathrm{t}-0) \\
(1.07,1.55)\end{array}$ & $\begin{array}{c}1.01(\mathrm{t}-0) \\
(0.97,1.05)\end{array}$ & $\begin{array}{c}1.02(\mathrm{t}-1) \\
(0.98,1.06)\end{array}$ & $\begin{array}{c}1.01(\mathrm{t}-1) \\
(0.99,1.02)\end{array}$ & $\begin{array}{c}1.03(t-0) \\
(0.95,1.12)\end{array}$ & $\begin{array}{c}1.04(t-0) \\
(0.94,1 \cdot 16)\end{array}$ \\
\hline Respiratory deaths & $\begin{array}{l}1.05(\mathrm{t}-3) \\
(1.02,1.09)\end{array}$ & $\begin{array}{l}1.02(\mathrm{t}-0-3) \dagger \\
(1.01,1.03)\end{array}$ & $\begin{array}{l}1.04(\mathrm{t}-0) \\
(1.00,1.09)\end{array}$ & $\begin{array}{c}0.97(\mathrm{t}-2) \\
(0.80,1.17)\end{array}$ & $\begin{array}{c}0.99(\mathrm{t}-2) \\
(0.98,1.01)\end{array}$ & $\begin{array}{c}1.01(\mathrm{t}-2) \\
(0.92,1.10)\end{array}$ & $\begin{array}{c}1.01(t-1) \\
(0.90,1.13)\end{array}$ \\
\hline Cardiovascular deaths & $\begin{array}{l}1.08(\mathrm{t}-0-3) \dagger \\
(1.03,1.12)\end{array}$ & $1.03(\mathrm{t}-1)$ & $\begin{array}{l}1.04(\mathrm{t}-2) \\
(0.99,1.10)\end{array}$ & $\begin{array}{l}1.01(t-1) \\
(0.96(1.05)\end{array}$ & $1.01(\mathrm{t}-2)$ & $1.00(\mathrm{t}-1)$ & $\begin{array}{c}0.94(t-1) \\
(0.82(1.09)\end{array}$ \\
\hline Digestive deaths & $\begin{array}{c}0.98(\mathrm{t}-0) \\
(0.85,1 \cdot 13)\end{array}$ & $\begin{array}{c}0.99(\mathrm{t}-0) \\
(0.88,1.11)\end{array}$ & $\begin{array}{c}1.51(\mathrm{t}-0) \\
(0.27,8.50)\end{array}$ & $\begin{array}{c}0.99(\mathrm{t}-1) \\
(0.95,1.02)\end{array}$ & $\begin{array}{c}0.99(\mathrm{t}-1) \\
(0.97,1.00)\end{array}$ & $\begin{array}{c}0.99(\mathrm{t}-0) \\
(0.91,1.07)\end{array}$ & $\begin{array}{c}0.99(-3) \\
(0 \cdot 89,1 \cdot 11)\end{array}$ \\
\hline
\end{tabular}

* $(\mathrm{t}-\mathrm{x})$ indicates the lag $(\mathrm{x})$ with the best fit.

$t(t-0-3)$ indicates the average values of $\mathrm{SO}_{2}$ (over lags 0 to 3 days) that best fit.

"low" values; this $60 \mu \mathrm{g} / \mathrm{m}^{3}$ limit was set because it represented the median value for several APHEA cities. In Lyon this cut-off point corresponded to the 85th centile of daily values, which actually is not "low"). The best model for $\mathrm{SO}_{2}$ over the whole period was therefore rerun, after introducing an interaction term between $\mathrm{SO}_{2}$ concentrations and this new binary variable for $\mathrm{PM}_{13}{ }^{22}$

Once the final model was fitted using linear regression, the corresponding variables (including lags and transforms) were input into a Poisson regression model whose results are presented below.

\section{Results}

As a general rule, the associations between mortality and air pollution were more significant using daily means or maximums, rather than averaging over many days' lag. Only these one day lag data will be presented, unless stated when averages over several days were more significant. This only occurs for $\mathrm{SO}_{2}$. All the regression parameters were converted into relative risks (RR) for a $50 \mu \mathrm{g} / \mathrm{m}^{3}$ increase of the concentration of pollutants. Since only relatively "moderate to low" levels of pollution

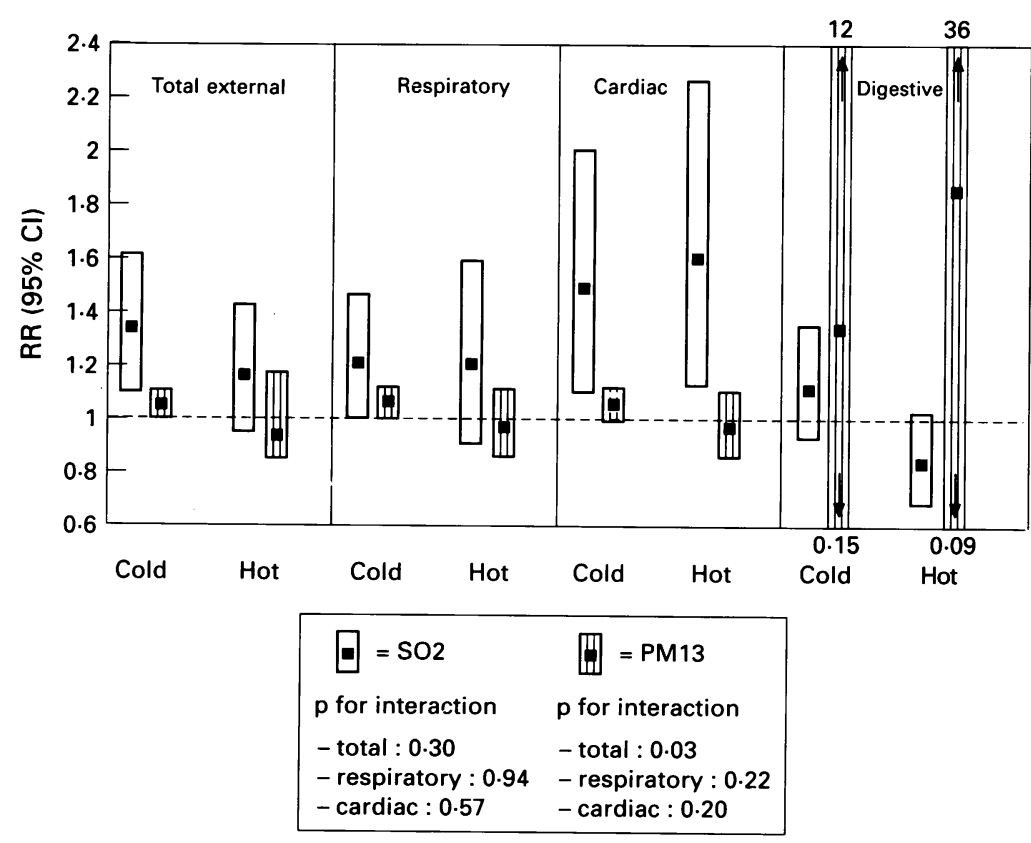

Figure 2 Seasonal variations in the relative risks (and 95\% confidence intervals) associated with a $50 \mathrm{\mu g} / \mathrm{m}^{3}$ increase in $\mathrm{SO}_{2}$ and $\mathrm{PM}_{13}$ in Lyon, France. were observed during the study period, this computation is most valid in the range of $0-150 \mu \mathrm{g} / \mathrm{m}^{3}$. Typically, the RRs represent the relative increase in mortality counts when the levels of pollutants step from 25 to $75 \mu \mathrm{g} / \mathrm{m}^{3}$ (or 50 to $100 \mu \mathrm{g} / \mathrm{m}^{3}$ ). Table 4 presents RRs for each pairwise association between pollutant and mortality category, along with their $95 \%$ confidence intervals, both for daily means and hourly maximums. In addition, the lags that gave the best fit of the models are indicated.

$\mathrm{SO}_{2}$ is the only pollutant that shows a clear association with mortality in the city of Lyon; it is associated with an increase in all causes of mortality except digestive conditions over the whole study period. The RRs linking $\mathrm{SO}_{2}$ to deaths from cardiovascular conditions are the greatest. No effect of particles was apparent over the whole study period for total mortality, but this is of borderline significance for respiratory and cardiovascular deaths. As expected, no pollutant exhibited any association with digestive mortality.

Figure 2 suggests that these effects have weak seasonal patterns. The RRs of respiratory and cardiovascular deaths associated with mean particulate concentrations seemed a little greater during the hot season. The $R R$ for a $50 \mu \mathrm{g} / \mathrm{m}^{3}$ increase in $\mathrm{PM}_{13}$ was 1.06 for respiratory mortality in the cold season and 0.98 in the hot season ( $\mathrm{p}$ for season interaction $=$ 0.22 ), while the respective RRs were 1.06 and 0.97 for cardiovascular mortality ( $p$ for season interaction $=0 \cdot 20$ ). The RRs were of borderline significance only during the cold season ( $p$ ranging from 0.04 to 0.07 ); the effect size was, however, always smaller than for the corresponding $\mathrm{SO}_{2}$ effect, which did not exhibit a seasonal variation. The data also suggested an interaction between particulates and $\mathrm{SO}_{2}$ whereby the $\mathrm{RR}$ of respiratory deaths associated with a $50 \mu \mathrm{g} / \mathrm{m}^{3}$ increase in daily mean of $\mathrm{SO}_{2}$ was greater when joint particulates concentrations were "high" (RR of 1.27 (95\% CI $1 \cdot 09,1 \cdot 47)$ when $\mathrm{PM}_{13}$ were greater than $60 \mu \mathrm{g} /$ $\mathrm{m}^{3}$ versus an $\mathrm{RR}$ of $1.19(1 \cdot 3,1 \cdot 37)$ when $\mathrm{PM}_{13}$ were less than $60 \mu \mathrm{g} / \mathrm{m}^{3} ; \mathrm{p}$ for interaction= $0.03)$. No clear pattern is shown for cardiovascular mortality. The Pearson correlation coefficient between $\mathrm{SO}_{2}$ and $\mathrm{PM}_{13}$ concentrations measured at the same monitoring site ranged between -0.08 to 0.76 according to season and location in Lyon, showing some independence between both pollutants that allow this pollutant interaction assessment. 


\section{Discussion}

The main results of this study are the following: (1) only $\mathrm{SO}_{2}$ and suspended particles showed an association with index categories of mortality; $\mathrm{NO}_{2}$ and $\mathrm{O}_{3}$ concentrations were unrelated to mortality. (2) $\mathrm{SO}_{2}$ was significantly associated with an excess risk of total deaths (minus external causes) and deaths from respiratory and cardiovascular conditions. The effect on respiratory mortality was increased when particulate concentrations were high; no seasonal modification or interaction with particulate pollution was noted for cardiovascular mortality. (3) Suspended particles were also associated with respiratory mortality and, although less clearly, with cardiovascular mortality; the regression coefficients were weaker than for $\mathrm{SO}_{2}$. The size of these associations was slightly increased during the cold season.

These results should be discussed in the light of the limitations of this study. The variability of the regression parameters and, thus, the levels of significance, depend heavily upon the size of the population. It should be noted that Lyon is the smallest town in the APHEA project, and this affects the counts of daily mortality $(0 \cdot 1 \%, 65 \%, 14 \%$, and $68 \%$ of days throughout the whole period had no mortality events, for total deaths minus external causes and deaths for respiratory, cardiovascular, and digestive conditions, respectively). This size limitation hampers a clear conclusion, on the subtle season or pollutants' combination effects.

As in all ecological type studies, exposure assessment is characterised by a high degree of misclassification. Indoor exposure to air pollutants cannot be controlled for with such a study design. Indoor air quality changes over time (people tend to open windows in summer and not in winter; indoor heating sources are used only during the cold season etc), and people spend more time outside in summer than in winter. The effect of this misclassification might be differential since, as a general rule, outdoor air tends to relate more closely to total personal exposure during the warm season than during the cold season, but its magnitude is difficult to assess. An effort was made to control for other factors that change over time, such as some meteorological variables and, of course, seasons and days of the week. However, the shape of the association with variables such as temperature and humidity might be more complex than can be modeled, and some residual confounding cannot be excluded. Other variables that characterise the population of Lyon, such as general housing conditions, age, gender, and smoking habits, do not change over time and thus should not confound the results since the time series approach utilises the population as its own control, without external unexposed population.

Another limitation concerns the configuration of the air quality monitoring network. The sites that were used were chosen in order to represent the background exposure to pollutants (and not extreme exposures such as the one indexed by the station located in a busy crossroad in the centre of Lyon). The ranges of concentrations are large enough for $\mathrm{SO}_{2}$, $\mathrm{PM}_{13}$, and $\mathrm{NO}_{2}$, giving some power to the study. For $\mathrm{O}_{3}$, however, whose only monitoring station during the study period was located downtown, the population of Lyon experienced very low exposures because of scavenging by the NO emitted by the traffic. Therefore, the lack of association between mortality and $\mathrm{O}_{3}$ has no general significance.

$\mathrm{NO}_{2}$ has been shown to be associated with respiratory symptoms and small reductions in pulmonary function, mostly in the context of indoor exposure and among children. ${ }^{2324}$ However, there is no evidence of an independent association with mortality in the epidemiological reports.

Suspended particles have been consistently related to short term mortality in different meteorological settings. The effect of $\mathrm{SO}_{2}$ is less clear. Often associated with particulates, its association with mortality is generally considered weaker, at least in many studies conducted in the US. Where both pollutants were measured, the statistical association of $\mathrm{SO}_{2}$ with mortality often decreased or disappeared where PM was also in the model..$^{2925}$ In some European data, however, the effect of $\mathrm{SO}_{2}$ persisted, ${ }^{2627}$ raising the question of the types of pollution blends indexed by the indicators PM and $\mathrm{SO}_{2}$ that might differ across continental and urban settings according to the sources of air pollutants. $\mathrm{SO}_{2}$ is one of many indicators of airborne acidity, along with acid aerosols whose untoward effects have been long established..$^{2829}$ In Lyon, the effect of $\mathrm{SO}_{2}$ on respiratory and cardiovascular mortality remained significant after adjustment for $\mathrm{PM}_{13}$ when both pollutants were kept in the model (data not presented). The interaction with season might also be explained by a change in such a complex pollution make up over time. In spite of the presence of seasonal terms in the models, some regression coefficients for $\mathrm{PM}_{13}$ still appeared greater in the cold than in the hot season. Both one day and "cumulative" exposure to air pollutants were considered in the data analysis because it had been suggested elsewhere ${ }^{56}$ that longer exposure might show a stronger association with mortality than peak exposure. This hypothesis is still unproved, at least by our data, and warrants other studies.

People who died on "high" pollution days were on average a little older than those who died on other days. When $\mathrm{SO}_{2}$ concentrations exceeded $100 \mu \mathrm{g} / \mathrm{m}^{3}$, the proportion of people older than 70 among those who died (total mortality) was greater $(72 \cdot 0 \%$ versus $69 \cdot 3 \%$, $\mathrm{p}=0.09$ ); this difference did not hold for $\mathrm{PM}_{13}$ $(70 \cdot 2 \%$ versus $69 \cdot 6 \%, p=0 \cdot 80)$. This result supports other findings showing that the elderly and those with acute or chronic respiratory and cardiac conditions are the sensitive population. ${ }^{4031} \mathrm{SO}_{2}$ and particulates per se may not be the primary agressors of the respiratory tract, but they can exacerbate preexisting conditions such as asthma, chronic bronchitis, and emphysema. This extra stress might thus trigger worsening of an existing disorder such as chronic cardiorespiratory 
deficiency. ${ }^{103233}$ A clear indication of this harvesting effect was given by the data from Erfurt, in East Germany. ${ }^{25}$

In conclusion, this study along with many other APHEA data described in this supplement add to the findings of previous short term mortality studies on particulate air pollution. It also stresses some characteristics of western European urban air where $\mathrm{SO}_{2}$ pollution still plays an important noxious role.

1 Dockery DW, Schwartz J, Spengler JD. Air pollution and daily mortality: associations with particulates and acid aerosol. Environ Res 1992;59:362-73.

2 Dockery DW, Pope CA. Acute respiratory effects of particulate air pollution. Annu Rev Public Health 1994;15: 107-32.

3 Fairley D. The relationship of daily mortality to suspended particulates in Santa Clara County, 1980-1986. Environ Health Perspect 1990;89:159-68.

4 Katsouyanni K, Karakatsani A, Messari I, et al. Air pollution and cause specific mortality in Athens. $\mathcal{f}$ Epidemiol Comand cause specific mortality in
munity Health 1990;44:321-24.

5 Kinney PL, Ito K, Thurston GD. A sensitivity analysis of mortality/PM 10 associations in Los Angeles. Inhalation Toxicology 1994;7:59-69.

6 Pope CA, Schwartz J, Ransom MR. Daily mortality and $\mathrm{PM}_{10}$ pollution in Utah Valley. Arch Environ Health 1992; 47:211-17

7 Schwartz J. Particulate air pollution and daily mortality in Detroit. Environ Res 1991;56:204-13.

8 Schwartz J, Dockery DW. Increased mortality in Philadelphia associated with daily air pollution concentrations. Am Rev Respir Dis 1992;145:600-4.

9 Schwartz J, Dockery DW. Particulate air pollution and daily mortality in Steubenville, Ohio. Am f Epidemiol 1992;135: $12-19$

10 Schwartz J. Air pollution and daily mortality: a review and meta-analysis. Environ Res 1994;64:36-52.

11 Spix C, Heinrich J, Dockery DW, et al. Air pollution and daily mortality in Erfürt, East Germany, 1980-1989, Envirn mortality in Erfürt, East Germany,
Health Perspect 1993;101:518-26.

12 Krzyzanowski M, Wojtyniak B. Ten-years mortality in a sample of an adult population in relation to air pollution. sample of an adult population in relation to air

13 Dockery DW, Pope CA, Xu X, et al. An association between air pollution and mortality in six US cities. $N$ Engl $\mathcal{F} \mathrm{Med}$ 1993;329:1753-9.

14 Pope CA, Thun MJ, Namboodiri MM, et al. Particulate pollution as a predictor of mortality in a prospective study of US adults. Am $\mathcal{F}$ Respir Crit Care Med 1995;151:669-74

15 Katsouyanni K, Zmirou D, Spix C, et al. Short-term effects of air pollution on health: a European approach using epidemiologic time-series data. Eur Resp $\mathcal{F}$ 1995;8:103081

16 ADEME (Agence de l'Environnement et de la Maîtrise de l'Energie). La qualité de l'air en 1992; zones urbaines, industrielles et rurales. Paris: ADEME, 1994; 147.

17 Stroebel R. La qualité de l'air en 1990 dans les zones urbaines, industrielles et rurales françaises. Pollution atmosphérique 1991;131:389-403.

18 Deriennic F, Richardson S, Mollie A, Lellouch J. Shortterm effects of sulfur dioxide pollution on mortality in term effects of sulfur dioxide pollution on mortal
two french cities. Int 7 Epidemiol 1989;18:186-97.

19 CSHPF (Conseil Supérieur d'Hygiène Publique de France). Particules en suspension dans l'atmosphère: effets sur la sante et proposition pour une révision des valeurs limites. Paris: Ministère des Affaires Sociales, de la Santé et de la Ville, 1993;82.

20 Katsouyanni K, Schwartz J, Spix C, et al. Short term effects of air pollution on health: a European approach using epidemiologic time series data: The APHEA protocol. Epidemiol Community Health, 1996;50(Suppl 1):S12-S18.

21 Schwartz J, Spix C, Touloumi G, et al. Methodological issues in studies of air pollution and daily counts of death or hospital admissions. 7 Epidemiol Community Health 1995;50(Suppl 1):S3-S11.

22 Zmirou 1991, Dechenaux J. L'effet conjoint de plusieurs polluants atmosphériques; une méta-analyse. Rev Epidémiol Santé Publ 1991;39:101-10.

23 Neas LM, Dockery DW, Ware JH, Spengler JD, Speizer FE, Ferris BG. Association of indoor nitrogen dioxide FE, Ferris BG. Association of indoor nitrogen dioxide with respiratory symptoms and pulmonary

24 Berglund M, Boström C-E, Bylin G, et al. Health risk evaluation of nitrogen oxides. Scand $\mathcal{F}$ Work Environ Health 1993;19(Suppl 2):72.

25 Spix C, Heinrich J, Dockery DW, et al. Air pollution and daily mortality in Erfurt, East Germany, 1980-1989. Environ Health Perspect 1993;101:518-26.

26 Hatzakis A, Katsouyanni K, Kalandidi A, Day $\mathrm{N}$, Trichopoulos D. Short-term effects of air pollution on mortality in Athens. Int $\mathcal{F}$ Epidemiol 1986;15:73-81.

27 Krzyzanowski M, Woytyniak B. Air pollution and daily mortality in Cracow. Public Health Rev 1991-92, 19:73-81.

28 Lippmann M. Airborne acidity. Estimates of exposure and human health effects. Environ Health Perspect 1985;63: 63-70.

29 Ostro BD, Lipsett MJ, Wiener MB, Selner JC. Asthmatic response to airborne acid aerosol. Am $f$ Public Health 1991;81:694-702.

30 Bates DV. Overview on characterizing study groups and their responses. In: Utell MJ, Franck R eds. Susceptibility to inhaled pollutants. Philadelphia: ASTM.

31 Schwartz J. What are people dying of on high air pollution days? Environ Res 1994;64:26-35.

32 Bates DU. Health indices of the adverse effects of air pollution: the question of coherence. Environ Res 1992 59:336-49.

33 Holland WW, Bennett AE, Cameron IR et al. Health effects of particulate pollution: reappraising the evidence. $\mathrm{Am} \mathcal{f}$ 